\title{
Kompetencje w zakresie języka angielskiego studentów niesłyszących i słabosłyszących w opinii ich lektorów
}

\begin{abstract}
Ewa Domagała-Zyśk, The Competences of deaf and hold of hearing (DHN) students in English as a foreign language - in the opinion of their teachers [Kompetencje $\mathrm{w}$ zakresie języka angielskiego studentów niesłyszących i słabosłyszących w opinii ich lektorów]. Interdyscyplinarne Konteksty Pedagogiki Specjalnej, nr 9, Poznań 2015. Pp. 27-43. Adam Mickiewicz University Press. ISBN 978-83-232-3051-9. ISSN 2300-391X
\end{abstract}

The purpose of this paper is to present the competences of deaf and hard of hearing (DHH) students in English as a foreign language - in the opinion of their teachers. There were 19 English teachers of the deaf and hard of hearing participating in this study and they represent 11 Polish and 8 foreign universities. The participants were asked to complete a questionnaire, evaluating their DHH students' competencies in reading, writing, lipreading/listening and speaking in English at the beginning and at the end of the students' formal English classes at the university. The results indicate a good potential of this group of students in mastering basic language skills, but also their considerable difficulties in terms of mastering a foreign language at higher levels. The article also contains recommendations of teachers regarding teaching strategies to improve the quality of education of this group of students.

KEY WORDS: deaf, hard-of-hearing, foreign language, language competences 


\section{Wstęp}

Osoby niesłyszące i słabosłyszące doświadczają wielu trudności w uczeniu się języka obcego, co związane jest nie tylko z tym, że muszą - tak jak wszyscy inni uczniowie - „złamać kod” nowego języka i nauczyć się posługiwać nim w celu wyrażenia własnych myśli i emocji, ale też pokonać ograniczenia związane $\mathrm{z}$ wadą słuchu. Naturą uszkodzenia słuchu - jak powiedział R.O. Cornett - nie jest bowiem problem mowy czy głosu, ale języka jako takiego ${ }^{1}$.

Przez prawie cały wiek XX uczniowie i studenci z uszkodzeniami słuchu nie uczyli się języków obcych - nie tylko w Polsce, ale i w innych krajach Europy Środkowej, gdzie nauka języka obcego była obowiązkowym przedmiotem dla uczniów słyszących. Zmiana tego trendu została wywołana zwiększającą się świadomością dobrego poziomu ogólnych kompetencji poznawczych osób z wadami słuchu, lepszymi możliwościami odbioru dźwięków wynikającymi z rozwoju nowych cyfrowych technologii produkowania aparatów słuchowych i implantów ślimakowych oraz tendencji integracyjnych i inkluzyjnych w edukacji. W efekcie tych zmian w Polsce od roku 2001 nauczanie języka obcego jest obligatoryjne także dla dzieci i młodzieży z uszkodzeniami słuchu, a podobne zmiany zaobserwowano również $\mathrm{w}$ innych krajach ${ }^{2}$, także na poziomie szkolnictwa wyższego ${ }^{3}$.

Celem własnych badań empirycznych przedstawionych $\mathrm{w}$ tym artykule jest przedstawienie kompetencji studentów niesłyszących

${ }^{1}$ Not the voice but the word - this is a real problem of the deaf - R.O. Cornett.

2 Por. np. E. Kontra, Language learning against the odds: retrospective accounts by Deaf adults, [w:] English as a foreign language for the deaf and hard of hearing persons in Europe, red. E. Domagała-Zyśk, Wydawnictwo KUL, Lublin 2013, s. 93-112.

${ }^{3}$ B. Gulati, Deaf students and English - the art of teaching and learning, [w:] English as a foreign language for the deaf and hard of hearing persons in Europe, red. E. DomagałaZyśk, Wydawnictwo KUL, Lublin 2013, s. 207-216; A. Nabiałek, From a blackboard to an interactive whiteboard. Teaching English as a foreign language to deaf and hard of hearing students at Adam Mickiewicz University in Poznań, [w:] English as a foreign..., op. cit., s. 197-206. 
i słabosłyszących w zakresie języka angielskiego jako obcego w ocenie ich lektorów. Badania miały charakter międzynarodowy, wzięło w nich udział 19 lektorów języka angielskiego pracujących z ponad 440 studentami z uszkodzeniami słuchu. Ewaluacja dokonana przez lektorów wskazuje na dobre możliwości tej grupy studentów w zakresie opanowania podstawowych sprawności językowych czytania, pisania, a nawet mówienia i odczytywania mowy obcojęzycznej z ust, ale jednocześnie duże trudności w zakresie opanowania języka obcego na wyższych poziomach jego znajomości. W artykule zawarto także rekomendacje lektorów dotyczące strategii nauczania poprawiających jakość kształcenia tej grupy studentów.

\section{Kompetencje osób niesłyszących i słabosłyszących w zakresie jezzyka angielskiego jako obcego}

Badania surdoglottodydaktyczne rozwijają się dopiero od niecałych dwóch dekad, co związane jest z pojawieniem się takiego pola badawczego na gruncie surdopedagogiki na początku obecnego wieku. Pierwsze publikacje w tym zakresie to artykuły Ewa Domagała-Zyśk ${ }^{4}$, Beata Gulati5 ${ }^{5}$ Edith Kontra ${ }^{6}$ oraz zbiór prac różnych autorów wydanych w monografii wieloautorskiej pod redakcją Cynthia Jane Kellet Bidoli i Elana Ochse7. Dały one początek wiedzy o specyficznych potrzebach uczniów i studentów niesłyszących i słabosłyszących oraz szansach na osiągnięcie przez nich sukcesu w za-

${ }^{4}$ E. Domagała-Zyśk, O uczeniu języka angielskiego uczniów z uszkodzeniem stuchu. Języki Obce w Szkole, 7, 2001, s. 106-110; E. Domagała-Zyśk, Czy istnieje już surdoglottodydaktyka?, "Języki Obce w Szkole", 4, 2003, 3-6.

${ }^{5}$ Ksztatcenie studentów niepetnosprawnych w zakresie języków obcych. Teaching foreign languages to disabled people, red. B. Harań, Wydawnictwo Akademii Podlaskiej, Siedlce 2005.

${ }^{6}$ A. Bajkó, E. Kontra, Language learners with special needs: An international perspective, [w:] Language learners with special needs: An international perspective, red. J. Kormos, E. Kontra, Multilingual Matters, Clevedon 2008, s. 158-188.

${ }^{7}$ English in International Deaf Communication, red. C.J. Kellett Bidoli, E. Ochse, Peter Lang, Bern 2008. 
kresie uczenia się języka obcego. Każda z tych publikacji, a także kolejne pozycje wyżej wymienionych autorów, są źródłem licznych wskazówek metodycznych, które mogą być wykorzystywane w celu podniesienia kompetencji językowych tej grupy uczniów. Lektorzy pracujący z uczniami i studentami z wadą słuchu odgrywają szczególną rolę w procesie nauczania. Oczekuje się od nich, aby byli specjalistami zarówno $\mathrm{w}$ zakresie nauczania języka, jak i pracy z osobami z wadą słuchu (surdopedagogami). Nie jest to latwe zadanie i wymaga podejmowania dodatkowego kształcenia czy też samokształcenia w kierunku dwuzawodowości, jednak $\mathrm{w}$ efekcie ta grupa nauczycieli ma bardzo dobre rozeznanie $\mathrm{w}$ zakresie potrzeb i możliwości swoich uczniów. Lektorzy ci pełnią nie tylko funkcję klasycznych nauczycieli, ale także tłumaczy, terapeutów, korepetytorów w zakresie wiedzy ogólnej czy doradców. Szczególnym zadaniem jest dla nich wypracowanie skutecznej formy komunikacji z uczestnikami lektoratu oraz modyfikowanie metod i technik nauczania tak, aby dostosować je do specjalnych potrzeb uczniów z wadą słuchu8.

Dotychczasowe badania w zakresie osiągnięć uczniów i studentów z wadami słuchu dają niejednoznaczne wyniki, najczęściej jednak wskazuje się na fakt, że w korzystnych warunkach edukacyjnych, do których zalicza się akceptowany i skutecznie wykorzystywany przez ucznia sposób komunikowania się (ustnie, przy pomocy języka migowego lub w technice mieszanej), wysoką motywację, realistyczne przekonania co do czynników warunkujących powodzenie w uczeniu się języka obcego, zwiększoną liczbę godzin nauki języ$\mathrm{ka}$, zindywidualizowane metody nauczania oraz dostosowany do potrzeb ucznia styl nauczania - uczestnicy lektoratu są $\mathrm{w}$ stanie czytać samodzielnie teksty dostosowane do ich możliwości, tworzyć zrozumiałe wypowiedzi pisemne, a niektórzy z nich są $\mathrm{w}$ sta-

8 D. Bedoin, English teachers of deaf and hard-of-hearing students in French schools: needs, barriers and strategies, "European Journal of Special Needs Education", 26, 2, 2011, s. 159-175; E. Domagała-Zyśk, Strategie nauczania języka angielskiego jako obcego uczniów z uszkodzeniami stuchu w szkołach podstawowych, gimnazjach i szkołach ponadgimnazjalnych, "Człowiek-Niepełnosprawność-Społeczeństwo”, 2012, 3 (17), s. 67-86. 
nie także porozumiewać się ustnie - odczytywać mowę obcojęzyczną z ust oraz mówić w języku obcym9.

Kompetencje w zakresie używania języka obcego przez dzieci i młodzież specjalnych szkół podstawowych, gimnazjów i szkół ponadgimnazjalnych zostały przeanalizowane $\mathrm{w}$ innej publikacji ${ }^{10}$. Wskazano w niej, że uczniowie z wadą słuchu w szkołach podstawowych najczęściej potrafią skomponować jedynie prosty tekst, złożony z kilku - kilkunastu zdań. Teksty te wykazują dobry stopień komunikatywności, jednak zawierają wiele struktur uproszczonych i niepoprawnych gramatycznie. Zaobserwowano także, że teksty pisane przez młodzież stają się coraz dłuższe i bardziej zrozumiałe, aby na poziomie studiów wyższych osiągnąć formę umożliwiającą samodzielne funkcjonowanie w środowisku posługującym się językiem angielskim - np. w czasie wyjazdu za granicę. Także inni autorzy podkreślają, że po kilku latach nauki języka osoby niesłyszące i słabosłyszące w sposób komunikatywny posługują się językiem obcym w piśmie i dzięki temu wykorzystują język obcy jako narzędzie komunikacji w edukacji, pracy zawodowej i rozryw$\mathrm{ce}^{11}$. Do tej pory nie badano jednak opinii lektorów na temat kompetencji w języku obcym studentów z wadą słuchu i niniejszy artykuł może zaradzić temu brakowi.

\section{Metodologia własnych badań empirycznych}

Celem własnych badań empirycznych prezentowanych w tym artykule było poznanie kompetencji studentów niesłyszących i słabosłyszących w zakresie języka angielskiego jako obcego - w opinii ich lektorów. Badania zaplanowano jako międzynarodowe i zapro-

${ }_{9}^{9}$ Por. E. Domagała-Zyśk, Wielojęzyczni. Studenci niestyszący i stabostyszący w procesie uczenia się nauczania języków obcych, Wydawnictwo KUL, Lublin 2013.

${ }^{10}$ E. Domagała-Zyśk, Written English of Polish deaf and hard of hearing grammar school students, [w:] English as a foreign..., op. cit., s. 163-180.

11 B. Gulati, op. cit., s. 207-216; A. Nabiałek, op. cit., s. 197-206. 
szenie do udziału w nich wysłano do wszystkich uczelni wyższych w Polsce oraz około 90 uczelni w różnych krajach Europy. W sumie udało się jednak zebrać tylko 19 ankiet - $11 \mathrm{z}$ nich pochodziło od nauczycieli z Polski (z następujących uczelni: Katolickiego Uniwersytetu Lubelskiego Jana Pawła II, Akademii Podlaskiej w Siedlcach, Uniwersytetu Warszawskiego, Uniwersytetu Jagiellońskiego, Uniwersytetu Pedagogicznego w Krakowie, Uniwersytetu Adama Mickiewicza w Poznaniu oraz Wyższej Szkoły Nauk Społecznych w Lublinie), zaś kolejnych 8 ankiet przesłano z 8 uczelni zagranicznych (Uniwersytetu Państwowego w Moskwie ${ }^{12}$, Uniwersytetu w Sannio, Uniwersytetu Masaryka w Brnie oraz Uniwersytetu Karola w Pradze). Z udziału w badaniach nie wykluczono żadnej osoby, która nadesłała swoje wypowiedzi, nie pominięto także świadomie żadnej informacji dotyczącej możliwości zaproszenia do badań lektorów nauczających studentów niesłyszących i słabosłyszących.

W badaniu zastosowano ankietę własnej konstrukcji: Foreign Language for the Deaf and Hard-of-Hearing (FLDHH). Ankieta składała się z 12 rozbudowanych pytań, głównie o charakterze opisowym. Pytania tworzyły 5 grup: 1. Informacje o badanych osobach - lektorach języka angielskiego; 2. Informacje o organizacji nauczania języka obcego studentów niesłyszących i słabosłyszących na uczelni; 3. Kompetencje studentów w zakresie czytania, pisania, słuchania/odczytywania mowy obcojęzycznej z ust i mówienia przed rozpoczęcie lektoratu na uczelni; 4 . Kompetencje studentów w zakresie czytania, pisania, słuchania/odczytywania mowy obcojęzycznej z ust i mówienia po zakończeniu lektoratu na uczelni; 5. Rekomendowane strategie nauczania.

\subsection{Charakterystyka lektorów - uczestników badań}

Nauczanie studentów niesłyszących i słabosłyszących prowadzone jest we wszystkich badanych ośrodkach przez osoby posia-

$12 \mathrm{~W}$ uczelni tej na kilku kierunkach studiów od lat funkcjonują specjalne grupy dla osób niesłyszących i słabosłyszących 
dające pełne kwalifikacje do nauczania języka obcego: 4 nauczycieli posiada tytuł doktora $\mathrm{w}$ dziedzinie nauk humanistycznych, $\mathrm{w}$ tym trzy osoby w zakresie języków obcych, 12 osób ma tytuł zawodowy magistra - M.A. w zakresie języka angielskiego, 3 osoby posiadają wyższe wykształcenie surdopedagogiczne i kwalifikacje do nauczania języka angielskiego. Jednocześnie należy zauważyć, że wśród nauczycieli posiadających wykształcenie językowe tylko 3 osoby jednocześnie ukończyły studia pedagogiczne w zakresie pedagogiki specjalnej, pozostali rozpoczęli pracę bez żadnego formalnego przygotowania do prowadzenia zajęć z uczniami o specjalnych potrzebach edukacyjnych.

Wszyscy nauczyciele byli lektorami języka angielskiego, ankiety zostały przez nich wypełnione $w$ tym języku. Brak lektorów innych języków wynika zapewne $\mathrm{z}$ dwóch powodów: trudności językowych $w$ dotarciu do grupy lektorów posługujących się językiem innym niż angielski, ale przede wszystkim z faktu, iż studenci niesłyszący i słabo słyszący uczą się głównie języka angielskiego jako języka obcego.

Uczestnicy badań należą do grupy nauczycieli o średnim i długim stażu pracy z osobami niesłyszącymi: 5 osób pracuje mniej niż dwa lata, 8 osób pracuje ponad dwa lata, ale mniej niż pięć lat, natomiast 6 osób pracuje dłużej niż sześć lat. W tym czasie każdy $\mathrm{z}$ nauczycieli uczestniczących $\mathrm{w}$ badaniach pracował $\mathrm{z}$ kilkoma lub kilkudziesięcioma studentami niesłyszącymi, łącznie badanych 19 nauczycieli udzielało odpowiedzi na podstawie swoich doświadczeń z osobistej pracy z grupą ponad 440 studentów niesłyszących.

Lektorów zapytano, ilu studentów niesłyszących i słabosłyszących uczy się języka obcego na uczelni, w której pracują. Analiza zebranych danych wskazuje, że największa grupa studentów z wadą słuchu uczy się języka angielskiego w Uniwersytecie Państwowym w Moskwie (około 250 studentów w ciągu 17 lat), Uniwersytecie w Sannio (Włochy - około 120 osób w ciągu 9 lat), Uniwersytecie Masaryka w Brnie (około 200 osób w ciągu 10 lat), Akademii Podlaskiej w Siedlcach (120 osób w ciągu 6 lat), Uniwersytecie Karola 
w Pradze (48 osób w ciągu 8 lat) i Katolickim Uniwersytecie Lubelskim Jana Pawła II (36 osób w ciągu 12 lat).

Interesujących danych dostarcza analiza motywów badanych nauczycieli do podjęcia pracy lektora studentów niesłyszących i słabosłyszących: nikt $\mathrm{z}$ badanych nie planował takiej formy pracy zawodowej, wszyscy poczuli się jednak w pewnym momencie „wezwani" do tego zadania i motywowani przez jego niezwykłość: "to było prawdziwe wyzwanie, a ja lubię wyzwania" (13L5, L8, L1514), chęć pomocy studentom, którym nikt inny nie chciał pomóc „nikt z lektorów nie chciał pracować z niesłyszącymi” (L6, L9, L14, L16) lub inspirację ze strony osób już pracujących w tym zawodzie (L7). Badani lektorzy nie poprzestają tylko na prowadzeniu zajęć językowych: praca z niesłyszącymi powoduje, że stali się zainteresowani specyfiką psychospołecznego funkcjonowania tej grupy, angażują się w pozauczelniane działania na rzecz osób niesłyszących i słabosłyszących, mają także wysoką motywację do kontynuowania takiej pracy (L1, L3, L4, L5, L6, L8, L9, L13, L14, L15)

\subsection{Formy organizacyjne lektoratu języka obcego dla studentów z uszkodzeniami słuchu w badanych uczelniach}

Analiza informacji dotyczących form organizacyjnych lektoratu wskazuje, że pierwsze specjalistyczne zajęcia dla studentów niesłyszących pojawiły się na uczelniach wyższych w latach 90. ubiegłego wieku - w 1994 r. w Uniwersytecie Państwowym w Moskwie, w 1998 r. w Uniwersytecie Karola w Pradze oraz w 1999 r. w Katolickim Uniwersytecie Lubelskim Jana Pawła II w Lublinie. W większości uczelni pojawienie się wśród studentów osób niesłyszących zanotowano dopiero w pierwszych latach XXI w., wtedy też rozpoczęło się tworzenie struktur umożliwiających udzielanie studentom niesłyszącym wsparcia w zakresie uczenia się języków obcych. Cen-

${ }^{13}$ Litera L i kolejny numer oznaczają poszczególnych lektorów - uczestników badań.

${ }^{14} \mathrm{~L}$ - oznacza lektora, ankiety ponumerowano w kolejności ich otrzymywania. 
tra wspierania edukacji osób z uszkodzeniami słuchu, których celem jest także organizowanie specjalistycznego wsparcia w zakresie nauczania języków obcych, powstały więc w Uniwersytecie Karola w Pradze (1998) i Uniwersytecie Masaryka w Brnie (2000), Uniwersytecie w Sannio (Włochy, 2001), Akademii Podlaskiej w Siedlcach (2004), Katolickim Uniwersytecie Lubelskim Jana Pawła II w Lublinie (2004) oraz Etvos Lorand Univeristy w Budapeszcie (2008). Studenci niesłyszący mogą realizować lektorat języka obcego w formie uczestnictwa $\mathrm{w}$ regularnych zajęciach lub też poprzez uczestnictwo $\mathrm{w}$ zajęciach specjalistycznych, przygotowanych wyłącznie dla studentów z uszkodzeniami słuchu.

\section{Kompetencje językowe studentów niesłyszących i słabosłyszących w świetle badań własnych}

W tej części przedstawione zostaną ogólne oraz szczegółowe kompetencje studentów nauczanych przez lektorów - uczestników badań.

\subsection{Ogólny poziom znajomości języka angielskiego jako obcego przed i po zakończeniu lektoratu na uczelni}

Lektorów poproszono o szacunkowe określenie poziomów znajomości języka obcego wśród nauczanych przez siebie studentów z wadą słuchu - uczestnicy badań ocenili go dla nauczanych przez siebie w ostatnich latach 442 osób z wadą słuchu. Wszyscy badani lektorzy zwracają uwagę na fakt, że poziom kompetencji studentów $\mathrm{z}$ wadą słuchu w zakresie języka angielskiego w chwili rozpoczęcia lektoratu języka obcego jest niższy w porównaniu do nauczanych przez nich regularnych grup studentów słyszących. Z szacunkowych danych przedstawionych przez lektorów dowiadujemy się, że rozpoczynając lektorat na uczelni wyższej, tylko 1,13\% studentów z wadą słuchu prezentowało poziom C2 ${ }^{15}$ (5 osób) a 1 osoba $(0,22 \%)$

${ }^{15}$ Poziomy określono według CERF. 
prezentowała poziom B2. Wśród pozostałych studentów 53,16\% osób znało język obcy na poziomie B1 (235 osób), 27,14\% (120 osób) na poziomie A2 zaś 18,32\% (81 osób) na poziomie A1.

Lektorów poproszono także o oszacowanie poziomu znajomości języka studentów z wadą słuchu po zakończeniu lektoratu. Największa grupa niesłyszących studentów zakończyła naukę języka na poziomie B2 (276 osób, 62,44\%), następnie A2 (152 osoby, $34,38 \%$ ) oraz B1 (103 osoby, 23,30\%). Analiza danych dotycząca początkowego i końcowego poziomu kompetencji nauczanych studentów wskazuje, że zasadniczo dokonują oni postępów w uczeniu się, jednak nie jest to poziom zadawalający: barierą wydaje się być przekroczenie progu poziomu B2, ponieważ spośród analizowanej

Tabela 4. Poziom znajomości języka obcego wśród studentów niesłyszących i słabosłyszących przed i po zakończeniu lektoratu na uczelni wyższej

\begin{tabular}{|l|c|c|c|c|}
\hline \multirow{2}{*}{$\begin{array}{c}\text { Poziom } \\
\text { znajomości } \\
\text { języka }\end{array}$} & $\begin{array}{c}\text { Poziom znajomości języka obcego } \\
\text { przed rozpoczęciem lektoratu }\end{array}$ & \multicolumn{2}{c|}{$\begin{array}{c}\text { Poziom znajomości języka } \\
\text { obcego po zakończeniu lektoratu }\end{array}$} \\
\cline { 2 - 5 } & $\mathrm{N}$ & $\%$ & $\mathrm{~N}$ & $\%$ \\
\hline A1 & 81 & 18,32 & 7 & 1,58 \\
\hline A2 & 120 & 27,14 & 152 & 34,38 \\
\hline B1 & 235 & 53,16 & 103 & 23,30 \\
\hline B2 & 1 & 0,22 & 276 & 62,44 \\
\hline C1 & 0 & 0,00 & 0 & 0,00 \\
\hline C2 & 5 & 1,13 & 6 & 1,35 \\
\hline Razem & 442 & 100 & 442 & 100 \\
\hline
\end{tabular}

Źródło: Badania własne - kwestionariusz FLDHH (poziomy wg. CERF)

grupy tylko 6 osób opanowało język obcy na poziomie C2, przy czym takiego postępu w ramach lektoratu na uczelni dokonała tylko 1 osoba. Stosunkowo duża grupa studentów pozostaje na poziomie znajomości podstaw języka (A1, A2): na tym początkowym etapie rozpoczyna lektorat na uczelni wyższej około $45 \%$ studentów niesłyszących, a pozostaje na nim 35\%, co oznacza, że jedna trzecia studentów z wadą słuchu kończy edukację uniwersytecką (poprze- 
dzoną często kilkoma latami nauki języka obcego w szkołach podstawowej i średniej), opanowując jedynie podstawy znajomości języka obcego. Dane te zebrano w tabeli 4.

\subsection{Kompetencje językowe studentów przed rozpoczęciem lektoratu na uczelni wyższej}

Proszeni o szczegółowe opisanie umiejętności studentów niesłyszących i słabosłyszących w zakresie czytania, pisania, słuchania i mówienia przed rozpoczęciem lektoratu, lektorzy pisali, iż studenci prezentowali zazwyczaj szczątkowe umiejętności w zakresie słuchania i mówienia, niektórzy $\mathrm{z}$ nich nie posługiwali się $\mathrm{w}$ ogóle mową w języku narodowym, w związku z czym nie uczyli się także mówić w języku obcym (angielskim). Część studentów umiało rozpoznać na ustach rozmówcy proste frazy w języku obcym i odpowiedzieć na zadane przez rozmówce pytanie (L8, L17, L8). Niestety, często zdarzało się zarówno w Polsce, jak i w innych krajach, że studenci niesłyszący i słabosłyszący, mimo fizycznych możliwości posługiwania się mową, dobrze mówiący w języku narodowym, trafiali na lektorat w uczelni wyższej bez wcześniejszych doświadczeń uczenia się mówienia w języku obcym, ponieważ w szkołach podstawowych i średnich byli nauczani jedynie pisania i czytania w języku obcym. Niezależnie od wcześniejszych doświadczeń niektórzy studenci niesłyszący komunikowali dopiero na etapie studiów wyższych pragnienie uczenia się mówienia w języku obcym (L8, L16, L17), chociaż efekty ich pracy nad wymową były wtedy znacznie słabsze niż w przypadku osób z wadą słuchu uczących się wymowy angielskiej w szkołach podstawowych i średnich (L2, L17). Lektorzy z Węgier zwrócili uwage na inny fakt: w integracyjnych szkołach węgierskich kładzie się duży nacisk na konieczność uczenia mowy uczniów niesłyszących, czego efektem jest, w przypadku niektórych uczniów, niechęć do uczenia się języka obcego w ogóle (L3, L4). W przypadku podejmowania prób uczenia wymowy nauczyciele wracali uwagę na brak czasu na wielokrotne powtarzanie oraz liczne błędy w wymowie utrudniające percepcję języka przez 
rozmówców (L12). Niektórzy studenci niesłyszący z kolei byli w stanie, pomimo głębokich uszkodzeń słuchu, porozumiewać się w języku obcym w czasie zagranicznych podróży i czerpali z tego ogromną satysfakcję (L16, L17).

W zakresie znajomości słownictwa i poziomu rozumienia czytanego tekstu najczęściej określano umiejętności studentów jako ubogie, pozwalające na rozróżnianie języka angielskiego od języka narodowego (L9), rozumienie poszczególnych wyrazów, ale bez umiejętności rozumienia tekstu ciągłego (L8), rozumienie jedynie bardzo prostych tekstów o zakresie słownictwa 500-1000 słów (L7). Przeszkodą w czytaniu ze zrozumieniem był dla studentów fakt braku znajomości znaczenia słów pojawiających się $\mathrm{w}$ tekście w języku narodowym, w związku z czym musieli stosować wysoce nieskuteczną technikę tłumaczenia "nieznanego przez nieznane”. Zdaniem lektorów jedynie niewielka grupa studentów niesłyszących i słabosłyszących prezentowała dobrą znajomość słownictwa i gramatyki, pozwalającą im na efektywne rozumienie tekstów podręcznikowych i popularnych (L7, L17).

Pisanie jest podstawową formą ekspresji językowej w przypadku studentów niesłyszących i słabosłyszących, jednak także tutaj badani lektorzy zauważyli liczne problemy: studenci niesłyszący, z którymi pracowali, tworzyli głównie teksty odtwórcze (L2), tylko nieliczni byli w stanie przygotować dłuższy tekst (jeden z lektorów określił, że tylko 2 z jego 17 studentów było w stanie przygotować wypracowanie powyżej 200 słów, L7). Większość jednak studentów już przed rozpoczęciem pracy na lektoracie umiało przygotować prosty list, wiadomość mailową lub sms w języku angielskim (L16, L12, L8).

\subsection{Kompetencje studentów po zakończeniu lektoratu w szkole wyższej}

Wszyscy badani lektorzy potwierdzili, że studenci niesłyszący i słabosłyszący poprawiają swój poziom znajomości języka angielskiego w czasie trwania lektoratu. Po jego zakończeniu byli w stanie 
odczytać prostą informację przekazaną mową, przedstawić się (L8), a także porozumieć się z nauczycielem i z innymi studentami, korzystając z mowy, odczytywania mowy z ust lub pisma (L8, N17). Ich wypowiedzi były jednak zazwyczaj odpowiedziami na proste pytania i nie byli oni w stanie podtrzymać dłuższej rozmowy (L5, L6). U studentów pracujących nad wymową uległa ona poprawie (L2, L8, L17), jednak zdaniem lektorów ćwiczenia nad wymową zabierają dużo czasu i w związku z tym były wykonywane przede wszystkim poza regularnymi zajęciami. Zwiększenie godzin przeznaczonych na lektorat języka obcego pozwoliłoby zapewne osiągnąć lepsze wyniki w tym zakresie. W czasie studiów zwiększa się motywacja do używania mowy obcojęzycznej (L14).

Kompetencje w zakresie rozumienia czytanego tekstu są tymi, w zakresie których następuje u studentów uczących się języka obcego najwyraźniejszy postęp. Po zakończeniu lektoratu byli oni w stanie czytać ze zrozumieniem teksty i na tej podstawie najczęściej uzyskać zaliczenie lektoratu na danym poziomie. Studenci czytali zarówno proste teksty użytkowe (ogłoszenia, listy), jak i teksty pomocne im w zakresie zdobywania wykształcenia zawodowego, np. teksty prawnicze (L14, L17) czy ekonomiczne (L17). Nauczyciele wypowiadali się optymistycznie o kompetencjach osób niesłyszących w zakresie czytania. Sądzą, że będą oni w stanie zrozumieć potrzebne im w dorosłym życiu teksty (L12), krytycznie analizować teksty w języku obcym (L5) i radzić sobie z funkcjonowaniem w krajach anglojęzycznych (L7).

W zakresie pisania lektorzy także odnotowali podwyższenie umiejętności, jednak część studentów nadal pozostała na poziomie pisania odtwórczego (N2). Tworzone teksty to najczęściej listy nieformalne (L5, L6), krótkie wiadomości mailowe, pocztówki z pozdrowieniami (L13, L14), odpowiedzi na ogłoszenia prasowe, życiorysy (L14, L17). Studenci niesłyszący i słabosłyszący na lektoracie nauczyli się zarówno tego, o czym mogą przygotować tekst, jak i tego jak to zrobić - opanowali zasady tworzenia struktury tekstu (L8, L17). Niektórzy uczestnicy lektoratu byli w stanie przygotować poważniejsze użytkowe wypowiedzi pisemne, np. wystąpienia czy prezentacje na konferencję (L16, L17). 


\section{Strategie nauczania stosowane przez lektorów}

W kwestionariuszu FLD lektorów zapytano o stosowane przez nich strategie nauczania studentów niesłyszących i słabosłyszących. Pytania miały formę otwartą. Zebrane odpowiedzi pogrupowano i przedstawiono poniżej. Niewielka liczba uczestników badań (19 lektorów) nie pozwoliła na zastosowanie statystycznej analizy danych.

Wypowiedzi lektorów wskazują, że stosują oni szereg różnorodnych strategii nauczania. Przede wszystkim wykorzystywane są wszelkie sytuacje, $\mathrm{w}$ których można skorzystać w procesie nauczania z pomocy wizualnych (L1, L2, L3, L6, L8, L10, L12, L13, L14, L16), czy to $\mathrm{w}$ formie realnych obiektów, czy też zdjęć, schematów, rysunków i ilustracji. Coraz częściej nauczyciele sięgają także po materiały przygotowane $z$ wykorzystaniem technologii informacyjnych i komunikacyjnych, np. po filmy $z$ napisami, prezentacje typu Power Point oraz materiały z Internetu (np. filmy z napisami z YouTube).

Percepcję wzrokową angażuje także wykorzystywane w większym zakresie niż w klasach regularnych pismo (L1, L2, L3, L4, L5, L6, L8, L10, L12, L13, L14, L15, L16, L17, L18, L19). Lektorzy wykorzystują je zarówno w formie zapisu na tablicy tradycyjnej (niektórzy postulują zapisywanie wszystkiego, co chce przekazać nauczyciel), tablicy interaktywnej, jak i na kartce papieru służącej do komunikacji. Przeważająca większość zadań wykonywanych przez studenta robiona jest w formie pisemnej: są to standardowe ćwiczenia leksykalne i gramatyczne, zindywidualizowane ćwiczenia przygotowane przez nauczyciela dla konkretnego ucznia, ćwiczenia pisemne służące rozwojowi zdolności komunikacyjnych (w formie tradycyjnej jest to tworzenie dialogu poprzez jego zapis na papierze, co możliwe jest także w formie elektronicznej w postaci czatu), tworzenie „zeszytów konwersowania”, gdzie uczeń zapisuje wszystkie dialogi odbyte na lekcji. Skuteczną zdaniem lektorów strategią jest wykorzystywanie ćwiczeń zawierających element aktywności fizycznej np. wymagających rysowania, przemieszczania się po sali, co może mieć formę gier zespołowych.

W opracowywaniu nowego materiału nauczyciele zalecają stosowanie strategii indukcyjnych (L5, L8, L10, L15, L16): wyjaśnienia reguł, a następnie ćwiczenia opracowywanej reguły. W opanowy- 
wania umiejętności czytania ze zrozumieniem przydatne jest przede wszystkim stosowanie takiej techniki komunikacyjnej, którą preferuje uczeń - języka migowego, fonogestów, palcowania, pisma aby środek komunikowania się nie zakłócał przebiegu zajęć, ale dawał możliwość jak najpełniejszego wyrażenia treści. Studenci migający powinni tłumaczyć tekst posługując się językiem migowym. Istotne znaczenie ma dobór tekstów, które nie powinny być przypadkowe, ale dostosowane do poziomu językowego ucznia i dotyczące tematyki, którą uczeń się interesuje, np. codzienne życie osób z uszkodzeniami słuchu w innych krajach, teksty humorystyczne, komiksy, quizy itp. Istotną strategią nauczania jest też powtarzanie uprzednio poznanych treści - należy na tę czynność poświecić zdecydowanie więcej czasu niż w przypadku uczniów słyszących. Ćwiczeniu wymowy służy zastosowanie międzynarodowego alfabetu fonetycznego (IPA) lub fonogestów oraz odwoływanie się do doświadczeń związanych z opanowywaniem przez ucznia fonetyki języka narodowego i ćwiczeń z zakresu terapii mowy. Wszyscy nauczyciele deklarują wykorzystywanie w procesie nauczania technologii informacyjnych i komunikacyjnych.

Lektorzy wyrażają także opinię, że konieczne jest profilowanie kursów językowych dla studentów niesłyszących i słabosłyszących: dla większości studentów znajomość języka obcego może być jednym z czynników warunkujących otrzymanie zatrudnienia, a w przyszłej pracy zawodowej zarówno w kraju, jak i za granicą będą prawdopodobnie zmuszeni korzystać ze znajomości języka angielskiego. Niestety, tylko w 3 uczelniach z badanych 11 studenci mają możliwość uczestniczenia w kursach częściowo dostosowanych do profilu studiów, dzięki czemu mają możliwość poznania słownictwa i wyrażeń potrzebnych w przyszłej pracy zawodowej.

\section{Zakończenie}

Podsumowując dane zebrane $\mathrm{w}$ referowanych $\mathrm{w}$ artykule własnych badaniach empirycznych, należy stwierdzić, że w opinii lektorów języka obcego studenci niesłyszący i słabosłyszący prezentują 
dość dobre kompetencje językowe. O ile kilkanaście lat temu trudno było znaleźć lektorów, którzy chcieliby podjąć pracę z uczniami czy studentami $z$ wadą słuchu, o tyle obecnie raczej stawiane jest pytanie - jak uczyć, żeby proces ten był jak najskuteczniejszy. Niestety, mało optymistyczny jest fakt, że pomimo wielu lat nauki języka obcego, ogromna większość studentów z wadą słuchu opanowuje język obcy na jednym z najniższych poziomów - 35\% studentów zna język obcy na poziomie A2. Konieczne są dalsze poszukiwania metodyczne, aby osoby niesłyszące i słabosłyszące mogły nie tylko uczestniczyć w lektoracie języka obcego, lecz także osiągać lepsze niż do tej pory efekty w tym zakresie.

\section{Bibliografia}

BAJKÓ A., KONTRA E., Language learners with special needs: An international perspective, [w:] Language learners with special needs: An international perspective, red. J. Kormos, E. Kontra, Multilingual Matters, Clevedon 2008.

BEDOIN D., English teachers of deaf and hard-of-hearing students in French schools: needs, barriers and strategies, "European Journal of Special Needs Education", 26, 2011, 2.

DOMAGAŁA-ZYŚK E., Czy istnieje już surdoglottodydaktyka?, „Języki Obce w Szkole”, 4, 2003.

DOMAGAŁA-ZYŚK E., O uczeniu języka angielskiego uczniów z uszkodzeniem stuchu. „Języki Obce w Szkole”, 7, 2001.

DOMAGAŁA-ZYŚK E., Strategie nauczania języka angielskiego jako obcego uczniów z uszkodzeniami stuchu w szkołach podstawowych, gimnazjach $i$ szkołach ponadgimnazjalnych. „Człowiek-Niepełnosprawność-Społeczeństwo”, 3 (17), 2012.

DOMAGAŁA-ZYŚK E., Wielojęzyczni. Studenci niestyszacy i stabostyszacy w procesie uczenia się nauczania języków obcych, Wydawnictwo KUL, Lublin 2013.

DOMAGAŁA-ZYŚK E., Written English of Polish deaf and hard of hearing grammar school students, [w:] English as a foreign language for the deaf and hard of hearing persons in Europe, Wydawnictwo KUL, Lublin 2013.

GULATI B., Deaf students and English - the art of teaching and learning, [w:] English as a foreign language for the deaf and hard of hearing persons in Europe, red. E. Domagała-Zyśk, Wydawnictwo KUL, Lublin 2013.

English in International Deaf Communication, red. Kellett Bidoli C.J., Ochse E. Peter Lang, Bern 2008. 
KONTRA E., Language learning against the odds: retrospective accounts by Deaf adults, [w:] English as a foreign language for the deaf and hard of hearing persons in Europe, red. E. Domagała-Zyśk, Wydawnictwo KUL, Lublin 2013.

Kształcenie studentów niepetnosprawnych w zakresie języków obcych. Teaching foreign languages to disabled people, red. Harań B. Wydawnictwo Akademii Podlaskiej, Siedlce 2005.

NABIAEEK A., From a blackboard to an interactive whiteboard. Teaching English as a foreign language to deaf and hard of hearing students at Adam Mickiewicz University in Poznan, [w:] English as a foreign language for the deaf and hard of hearing persons in Europe, red. E. Domagała-Zyśk, Wydawnictwo KUL, Lublin 2013. 